\title{
Towards a new biological control approach for Photorhabdus temperata bioinsecticide production through the bioconversion of Tunisian industrial wastewater
}

\author{
Sahar Keskes ${ }^{1}$, Wafa Jallouli ${ }^{*}$, Emna Sahli ${ }^{2}$, Sami Sayadi ${ }^{3}$ and Slim Tounsi ${ }^{1}$
}

\begin{abstract}
A novel bioconversion approach of Tunisian wastewater to low-cost Photorhabdus temperata bioinsecticide is presented in this study. Our results showed that when cultured on the food industry wastewater (WS4), P. temperata cells exhibited oral toxicity of about 42\%, which is the same as those cultured in complex medium (CM), used as control. Moreover, variants small colony polymorphism (Vsm) of the strain K122 was completely avoided after a prolonged incubation. However, viable but non-culturable (VBNC) state was enhanced with the maximum colony-forming units (CFU) count of $9 \times 10^{6}$ cells $/ \mathrm{mL}$ obtained after $48 \mathrm{~h}$ of incubation in the WS4. According to flow cytometry analysis, almost $100 \%$ of $P$. temperata cells were viable until $48 \mathrm{~h}$ of incubation. The appearance of propidium iodide (PI) positively stained cells was observed after a prolonged incubation with a maximum of $17 \%$ of damaged cells in WS1. In order to follow the progress of P. temperata fermentation process carried out in industrial wastewater, we established for the first time, the mathematical relationship between total cell counts, CFU counts and oral toxicity of P. temperata strain K122. Indeed, irrespective of the medium used, the relationship between CFU count and total cell count followed a power law. Additionally, when plotting CFU count, or total cell count against toxicity, a semi-log linear relationship was obtained. Our results proved the efficiency of this bioconversion approach to produce bioinsecticide based on the entomopathogenic bacterium P. temperata, with practical benefits in terms of cost production and wastewater management.
\end{abstract}

Keywords: Photorhabdus temperata strain K122, Tunisian industrial wastewater, Mathematical relation, Toxicity, flow cytometry, Viable but non-culturable state

\section{Introduction}

Industrial wastewater is considered to be high strength due to their color, high nutrient content, high carbon oxygen demand (COD) value and presence of suspended solids, which limits their discharge into water bodies (Gupta et al. 2019). The treatment of wastewater is considered as an integral part of the environmental pollution control. The treated wastewater volume in Tunisia was

\footnotetext{
*Correspondence: jallouliwafa2@yahoo.fr

1 Biopesticides Laboratory, Centre of Biotechnology of Sfax, Sfax University, P.O. Box'1177', 3018 Sfax, Tunisia

Full list of author information is available at the end of the article
}

about 260 million cubic meters $\left(\mathrm{mm}^{3}\right)$ in 2017. However, only $29 \%$ of these effluents are exploited, mainly in agriculture, and the rest is released into the sea (Zouari et al. 2019). Treatment of wastewater is energy consuming and not allowed to remove completely COD from this effluent. Consequently, research institutions are directing their efforts towards the bioconversion of industrial wastewater, which is an approach providing economic solution for sustainable wastewater management. Moreover, this approach avoids contamination of soil and vegetables by heavy metals found at high concentration in the treated wastewater used for irrigation (Rezapour 
et al. 2019). Several reports described the bioconversion of industrial wastewater and wastewater sludge by using different microorganisms, such as Bacillus thuringiensis, Sinorhizobium meloliti and microalgae species. Indeed, wastewater contains organic carbon, as well as nutrients like nitrogen, and phosphor allowing their growth and generation of value-added products including biopesticides, legume inoculants and biofuel, respectively (Yezza et al. 2006; Ben Rebah et al. 2002; Gupta et al. 2019). However, there is no report describing the use of wastewater for Photorhabdus bioinsecticide production.

Photorhabdus temperata is a symbiotic bacterium of the entomopathogenic nematode Heterorhabditis downesii K122 (Stock et al. 2002). It is characterized by the production of different insecticidal proteins like the toxin complexes (Tc) (Waterfield et al. 2001) and the "makes caterpillars floppy" (Mcf) toxins (Daborn et al. 2002). These toxins have been successfully used as bioinsecticides against very diverse insect orders, either by ingestion (Jallouli et al. 2013) or injection into the hemolymph (Jang et al. 2011; Ullah et al. 2017). Investigation of $P$. temperata oral toxicity has been reported in several studies. Indeed, when tested against different development stages of the polyphagous pest Tetranychus urticae, P. temperata cell-free supernatant caused 60, 64, 92 and $52 \%$ mortality of protonymph, deutonymph, adult males and adult females, respectively (Eroglu et al. 2019). Moreover, Shrestha and Lee (2012) demonstrated that after oral ingestion, the bacterial free supernatant of the culture medium from $P$. temperata, caused mortality of the adult sweet potato whitefly Bemisia tabaci, and was completely lethal after $60 \mathrm{~h}$ post-treatment. P. temperata was also demonstrated to be orally toxic against the flour moth Ephestia kuehniella, since a concentration of $12 \times 10^{8}$ cells $/ \mathrm{mL}$ caused $100 \%$ mortality of this insect larvae (Jallouli et al. 2013). In addition, an Escherichia coli cosmid clone, containing the $m c f$ gene from P. temperata, was demonstrated to be highly virulent after injection into Galleria mellonella and Tenebrio molitor, by causing the loss of body turgor of both larvae (Ullah et al. 2014). Moreover, $100 \%$ mortality of G. mellonella was obtained after injecting of $P$. temperata whole cells, soluble extract or supernatant (Jang et al. 2011; Ullah et al. 2017).

For commercial production of Photorhabdus bioinsecticides, low-cost nutrients must be selected since the cost of raw materials may comprise between 30 and $40 \%$ of the overall production cost (Montiel et al. 2001). The use of wastewater, as an alternative medium production, has the advantages to be zero cost and permanently available. The only low-cost Photorhabdus fermentation medium is based on an agro-commercial industrial source which is soya bean meal used at $10 \mathrm{~g} / \mathrm{L}$ (Jallouli et al. 2011). When cultured in CM (complex medium), the strain K122 of P. temperata could be maintained at the primary form and did not develop variants small colony (Vsm) polymorphism after a prolonged incubation. Indeed, $P$. temperata Vsm forms appear in three types of small colonies (white, red and yellow), during fermentation process, starting from $72 \mathrm{~h}$ of incubation and are characterized by a low toxicity against insect larvae (Jallouli et al. 2008). Additionally, the VBNC (viable but non-culturable) state, characterizing the strain K122, was partially overcome, since growth occurred at low cell density of $6.2 \times 10^{8}$ cells $/ \mathrm{mL}$. Entry of the strain K122 into the VBNC state was due to oxidative stress generated by hydrogen peroxide, and was demonstrated to be enhanced by the growth at high cell density (Jallouli et al. 2010). In addition, the determination of insecticidal toxicity against $E$. kuehniella showed that $P$. temperata cells produced in $\mathrm{CM}$, exhibited an oral toxicity of $38 \%$ at a cell density of $4 \times 10^{8}$ cells $/ \mathrm{mL}$ (Jallouli et al. 2011).

Here, we propose the bioconversion of Tunisian industrial wastewater as a novel approach to produce lowcost $P$. temperata bioinsecticide. Total cell count, CFU count, oral toxicity against the flour moth E. kuehniella and physiological state analysis by flow cytometry, were conducted during growth in industrial wastewater. These analyses allowed us to select the appropriate medium maintaining $P$. temperata viability and ensuring maximal oral toxicity. The established relationships between the determined parameters could be used to follow the progress of $P$. temperata fermentation process.

\section{Materials and methods Microorganisms}

The bacterial strains used in this study were $P$. temperata ssp. temperata strain $\mathrm{K} 122$ and $P$. luminescens strain Q167/2, obtained from CNRS (Gif-sur-Yvette, France). Cultures of both strains were maintained by streak inoculating LB agar Petri dishes (Sambrook et al. 1989), incubated at $30{ }^{\circ} \mathrm{C}$ for $48 \mathrm{~h}$ and then stored at $4{ }^{\circ} \mathrm{C}$ for future use.

\section{Biopesticide production media}

In this study, six media were used: five industrial wastewaters and a $\mathrm{CM}$ used as a control. The composition of CM was as follow (g/L): $\mathrm{Na}_{2} \mathrm{HPO}_{4}, 2 \mathrm{H}_{2} \mathrm{O}$ 1.2, $\mathrm{NH}_{4} \mathrm{Cl}$ 1.07, $\mathrm{KCl} 0.35, \mathrm{C}_{6} \mathrm{H}_{5} \mathrm{O}_{7} \mathrm{Na}_{3} 2 \mathrm{H}_{2} \mathrm{O} 0.5, \mathrm{Na}_{2} \mathrm{SO}_{4}$ $0.28, \mathrm{MgCl}_{2}$ 0.12, $\mathrm{CaCl}_{2}$ 0.05, $\mathrm{NaCl} 0.037, \mathrm{FeCl}_{3}-6 \mathrm{H}_{2} \mathrm{O}$ 0.0017 and soya bean meal 10 (Jallouli et al. 2011). It contains a total solid (TS) concentration of $11.85 \mathrm{~g} / \mathrm{L}$, a total organic carbon (TOC) of $1052.14 \mathrm{mg} / \mathrm{mL}$ and total nitrogen $(\mathrm{Nt})$ of $500 \mathrm{mg} / \mathrm{mL}$. The commercial soya bean meal was obtained from the local cattle feed producer (ALCO, Sfax, Tunisia). The industrial wastewaters (WS1 and WS2) were sampled from the food industry 
GIPA (Genérale Industrie des Produits Alimentaires, Sfax, Tunisia). The wastewater (WS3) was collected from pharmaceutical industry (Simed, Sfax, Tunisia). The wastewater (WS4) was sampled from the food industry STL (Société Tunisienne de Levure, Beja, Tunisia). The wastewater (WS5) was collected from poultry farming (Dick Couvoirs, Sfax, Tunisia). pHs were adjusted to 7.0 using $1 \mathrm{~N} \mathrm{HCl}$ or $\mathrm{NaOH}$ before sterilization for $20 \mathrm{~min}$ at $121^{\circ} \mathrm{C}$

\section{Wastewater analyses}

The determination of total solids, volatile solids (VS), suspended solids (SS) and volatile suspended solids (VSS) were carried out according to standard methods (APHA 1992). The total Kjeldahl nitrogen content was determined as described by Kjeldahl (1883). Total organic carbon determination was carried out with Shimadzu TOC analyzer TOC-VCPH according to standard methods (APHA 1992). Metals $\left(\mathrm{Pb}^{2+}, \mathrm{Mn}^{2+}, \mathrm{Fe}^{2+}, \mathrm{Cu}^{2+}, \mathrm{Zn}^{2+}\right.$, $\mathrm{Cd}^{2+}, \mathrm{Cr}^{2+}, \mathrm{Ni}^{2+}, \mathrm{Ca}^{2+}, \mathrm{Mg}^{2+}, \mathrm{Na}^{+}$and $\mathrm{K}^{+}$) were analyzed by atomic absorption spectroscopy: samples were first attacked by hot acid solutions $\left(\mathrm{HCl}, \mathrm{HNO}_{3}\right)$, then filtered and finally identified by atomic absorption spectroscopy technique using a device "Perkin Elmer A Analyst 200 atomic absorption spectrometer".

\section{Inoculum preparation and growth experiments}

The inoculum was prepared as follows: one 48-h-old $P$. temperata strain $\mathrm{K} 122$ was isolated and dispersed into $3 \mathrm{~mL}$ of LB medium and incubated overnight at $30{ }^{\circ} \mathrm{C}$. The seed culture was used to inoculate $500-\mathrm{mL}$ Erlenmeyer flasks containing $85 \mathrm{~mL}$ of different media quoted above, with initial optical density of 0.025 at $725 \mathrm{~nm}$ (Jallouli et al. 2008). Incubation was carried out during $96 \mathrm{~h}$ in a rotary shaker set at $200 \mathrm{rpm}$ and at a temperature of $30{ }^{\circ} \mathrm{C}$ (Jallouli et al. 2008).

\section{Flow cytometry}

Cell viability analysis by flow cytometry was conducted with an Attune Nxt Acoustic Focusing Flow Cytometer (Thermo fisher) equipped with a 488 argon laser and two physical light scattering parameters: the forward scatter (FSC) and the sideward scatter (SSC), measuring cell size and granularity, respectively. Three fluorescence signals were collected with photomultiplier tubes: green fluorescence FL1 (530 $\pm 30 \mathrm{~nm})$, orange fluorescence FL2 $(574 \pm 26 \mathrm{~nm})$, and red fluorescence FL3 $(695 \pm 40 \mathrm{~nm})$. Fluorescent beads of $1 \mu \mathrm{m}$ in diameter were added in order to normalize the flow cytometer settings. Samples from different $P$. temperata culture broth (WS1, WS2, WS3, WS4, WS5 and CM) were collected at different incubation times $(24,48$, and $72 \mathrm{~h})$. For determination of cell viability, all the samples were immediately diluted with PBS $1 \times \mathrm{pH} 7.2$ and stained with propidium iodide (PI) (Sigma-Aldrich) at a final concentration of $10 \mu \mathrm{g} / \mathrm{mL}$. Samples were incubated for $15 \mathrm{~min}$ in the dark. PI fluorescence was measured using the red $695 \pm 40 \mathrm{~nm}$ band pass filter (FL3). For each sample data were collected for 10.000 events, using logarithmic amplification, at a flow rate of $25 \mu \mathrm{L} / \mathrm{min}$. Heat-treated cells were used as a positive controls and each assay was run in duplicate.

\section{Analyses}

\section{Estimation of total cell count}

Photorhabdus temperata cells count was determined microscopically, using Thoma counting chamber, by a microscope (ZUZI) at 100-fold magnification. The presented values are the average results $( \pm$ standard deviation (SD)) of three determinations of three separate experiments.

For media inoculation, the optical density (OD) was determined in LB medium at $725 \mathrm{~nm}$ (Jallouli et al. 2008), with a spectral photometer (BioRad).

\section{Estimation of culturable cell count}

Photorhabdus temperata cell culturability was performed by counting CFU grown on solid LB medium after different incubation times. Incubation of LB plates was carried out at $30{ }^{\circ} \mathrm{C}$ during $48 \mathrm{~h}$ and prolonged up to $96 \mathrm{~h}$ for detection of Vsm colonies (Jallouli et al. 2008). Each type of colony was identified by shape and color. The presented values are the average results $( \pm S D)$ of three determinations of three separate experiments.

\section{Bioassays}

Oral toxicity of $P$. temperata was estimated against first instar larvae of E. kuehniella using optimized-conditions in our laboratory (Jallouli et al. 2008). P. temperata toxicity was assessed as the growth inhibition of the fed larvae with $\mathrm{K} 122$, compared to the growth of similar larvae number fed with the non-toxic P. luminescens strain Q used as control (Jallouli et al. 2013). Growth inhibition was determined by using similar cell count of $4 \times 10^{8}$ cells $/ \mathrm{mL}$ at different fermentation times. The presented values are the means $( \pm \mathrm{SD})$ of the weight of 30 larvae collected from three replicates carried out with 10 larvae each. The data were statistically analyzed by SPSS software (Version 20) using Duncan test performed after analysis of variance (ANOVA).

\section{Analyses of relationship between total cell count, CFU count and toxicity}

Data obtained from experiments using WS1, WS2, WS3, WS4, WS5 and CM media were used to analyze the relationships between total cell count and CFU, total cell count and toxicity, and between CFU count and toxicity. 
Linear, logarithmic, exponential and power law relationships between determined parameters were carried out, and the adequate one was chosen for presentation.

\section{Results}

\section{Wastewater characterization}

The composition of different wastewaters is presented in Table 1. The volatile solid was the highest in WS4 $(4.7 \mathrm{~g} / \mathrm{L})$. This concentration decreased to $1.54,1.19,1.08$ and $0.83 \mathrm{~g} / \mathrm{L}$ in WS1, WS5, WS2 and WS3, respectively. The $\mathrm{pH}$ varied from 7 to 8 in wastewaters WS4, WS3, WS5 and WS2, but it is of 10.32 in WS1. Chemical characterization showed that WS4 had the highest total organic carbon (TOC) and total nitrogen (Nt), compared to the other wastewaters used in this study. Metal quantification showed that the concentrations of $\mathrm{Ca}^{2+}, \mathrm{Mg}^{2+}, \mathrm{Na}^{+}$, and $\mathrm{K}^{+}$were the highest in all wastewaters used, compared to heavy metals which are present at a low concentration.

\section{P. temperata growth, culturability and entomotoxicity in different cultivation media}

When using wastewater as a fermentation medium for $P$. temperata bioinsecticide production, stationary phase started at $30 \mathrm{~h}$ in all the media tested, leading to a final biomass of 4.1, 5.2, 6.5, 7.1 and $7.5 \times 10^{8}$ cells $/ \mathrm{mL}$ in WS4, WS5, WS2, WS1 and WS3, respectively (Fig. 1a). Biomass production is comparable to that obtained in CM $\left(6.24 \times 10^{8}\right.$ cells $\left./ \mathrm{mL}\right)$.

Contrarily to CM, showing the highest CFU counts of $2.72 \times 10^{7}$ cells $/ \mathrm{mL}$ after $31 \mathrm{~h}$ of fermentation, the strain K122 exhibited a lower culturability in all the wastewaters tested. Indeed, by using wastewater WS4 as a raw material for $P$. temperata growth, the CFU titer was of $9 \times 10^{6}$ cells $/ \mathrm{mL}$ followed by a maximum CFU counts of $6.95,4.8,3.5$, and $1.9 \times 10^{6}$ cells $/ \mathrm{mL}$ obtained by using WS1, WS2, WS5 and WS3, respectively (Fig. 1b). It is important to note that stability of CFU counts after plating cells on LB agar differs significantly between media used for $P$. temperata cultivation (Fig. 1b). In fact, K122 cells were more culturable in WS4, since CFU counts started to decline after $78 \mathrm{~h}$ of fermentation similar to those cultivated in CM and in WS3. However, when using WS1, WS2 and WS5, the ability of the strain K122 to form colonies started to decrease after $48 \mathrm{~h}$ of incubation.

The profile of insecticidal activity against E. kuehniella larvae, in various fermentation media, is presented in Fig. 1c. It is important to note that in all the fermentation media, the highest toxicity was obtained by using

Table 1 Physico-chemical characteristics of industrial wastewaters used for $P$. temperata bioinsecticide production

\begin{tabular}{|c|c|c|c|c|c|}
\hline Characteristics & WS1 & WS2 & WS3 & WS4 & WS5 \\
\hline \multicolumn{6}{|c|}{ Physical characteristics } \\
\hline $\mathrm{TS}(\mathrm{g} / \mathrm{L})$ & $4.24 \pm 0.05$ & $3.18 \pm 0.05$ & $1.32 \pm 0.58$ & $7.2 \pm 0.11$ & $6 \pm 0.19$ \\
\hline VS (g/L) & $1.54 \pm 0.23$ & $1.08 \pm 0.07$ & $0.83 \pm 0.05$ & $4.7 \pm 0.22$ & $1.19 \pm 0.45$ \\
\hline SS (g/L) & $0.16 \pm 0.002$ & $0.4 \pm 0.02$ & $0 \pm 0$ & $0.4 \pm 0.1$ & $0 \pm 0$ \\
\hline VSS (g/L) & $0.10 \pm 0.009$ & $0.084 \pm 0.001$ & $0 \pm 0$ & $0.4 \pm 0.05$ & $0 \pm 0$ \\
\hline $\mathrm{pH}$ & 10.32 & 8 & 6.91 & 7.01 & 8.03 \\
\hline \multicolumn{6}{|c|}{ Chemical characteristics } \\
\hline $\mathrm{TC}(\mathrm{mg} / \mathrm{L})$ & 1220 & 195.4 & 1753 & 1892 & 144.6 \\
\hline TOC (mg/L) & 1104 & 105.5 & 1747 & 1828 & 94.6 \\
\hline $\mathrm{Nt}(\mathrm{mg} / \mathrm{L})$ & 77 & 76.3 & 83.3 & 403.2 & 17.5 \\
\hline \multicolumn{6}{|l|}{ Metals (mg/L) } \\
\hline $\mathrm{Pb}^{2+}$ & 0.16 & $<0.05$ & $<0.05$ & $<0.05$ & $<0.05$ \\
\hline $\mathrm{Mn}^{2+}$ & $<0.04$ & $<0.04$ & $<0.04$ & $<0.04$ & $<0.04$ \\
\hline $\mathrm{Fe}^{2+}$ & 0.23 & $<0.06$ & 0.1 & 0.34 & 0.07 \\
\hline $\mathrm{Cu}^{2+}$ & $<0.05$ & $<0.05$ & $<0.05$ & $<0.05$ & $<0.05$ \\
\hline $\mathrm{Zn}^{2+}$ & 0.4 & 0.1 & 0.03 & 0.07 & 0.1 \\
\hline $\mathrm{Cd}^{2+}$ & $<0.005$ & $<0.005$ & $<0.005$ & $<0.005$ & $<0.005$ \\
\hline $\mathrm{Cr}^{2+}$ & $<0.05$ & $<0.05$ & $<0.05$ & $<0.05$ & $<0.05$ \\
\hline $\mathrm{Ni}^{2+}$ & $<0.01$ & $<0.01$ & $<0.01$ & $<0.01$ & $<0.01$ \\
\hline $\mathrm{Ca}^{2+}$ & 135 & 52 & 175 & 66 & 120 \\
\hline $\mathrm{Mg}^{2+}$ & 7.6 & 4.6 & 2 & 4 & 14.4 \\
\hline $\mathrm{Na}^{+}$ & 165 & 158 & 35 & 15 & 298 \\
\hline $\mathrm{K}^{+}$ & 4 & 2 & ND & 4 & 10 \\
\hline
\end{tabular}


P. temperata cells aged for $31 \mathrm{~h}$ and remained stable by using those aged for $48 \mathrm{~h}(p<0.05)$. However, oral toxicity against $E$. kuehniella larvae was the lowest when bioassay was carried out by using cells aged for $24 \mathrm{~h}$ $(p<0.05)$. After $48 \mathrm{~h}$ of incubation, the analysis of variance (ANOVA) showed no statistical difference $(p>0.05)$ between $P$. temperata oral toxicity cultured in CM or WS4 with an inhibition growth of $42 \%$ and $38 \%$, respectively. In contrast, lower toxicity $(p<0.05)$ of $29.5 \%$, $15.37 \%, 14.33 \%$ and $9.75 \%$ was obtained for P. temperata cells cultured in WS1, WS5, WS2, and WS3, respectively.

\section{Cell physiology study by flow cytometry}

The analysis of $P$. temperata physiological state, cultured in different fermentation media, is presented in Fig. 2. When cultured in CM, used as control, K122 cells were all viable ones (PI negatively stained) after different incubation times (24, 48 and 72 h) (Fig. 2A). In contrast, during the growth in wastewater, there was a change in $P$. temperata physiological state. Indeed, when using WS1, WS2, WS3 or WS5 as fermentation medium the percentage of dead cells (PI positively stained) increased progressively from 2, 1.9, 0.8 and $1.8 \%$ at $48 \mathrm{~h}$ of incubation, to $17,7.8,9.4$ and $9.8 \%$, respectively, at $72 \mathrm{~h}$ of incubation. Interestingly, almost all $P$. temperata cells remained viable even after a prolonged incubation in WS4 with only $0.8 \%$ of dead cells at $72 \mathrm{~h}$ of incubation (Fig. 2B). At such incubation time, the percentage of $\mathrm{K} 122$ damaged-cells followed the order: WS $1^{>} \mathrm{WS}^{>}{ }^{\text {WS }} 3^{>} \mathrm{WS} 2{ }^{>} \mathrm{WS} 44^{>} \mathrm{CM}$.

\section{Relationship between total cell count, CFU count and toxicity in different media Relationship between total cell count and CFU count} Irrespective of the medium used for $P$. temperata bioinsecticide production, the relation between CFU count and total cell count could be expressed by a power law function: $\mathrm{CFU}=a$ (total cell count) $^{b}$ (Fig. 3a).

Power law equations from (1) to (6) are presented below:

$\mathrm{MC}: \mathrm{CFU}=4.596$ (total cell count $)^{0.987} ; R^{2}=0.998$,

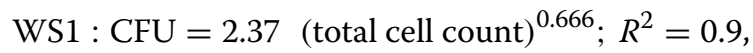

WS2 $:$ CFU $=1.823(\text { total cell count })^{0.677} ; R^{2}=0.866$,

WS3 $:$ CFU $=0.687$ (total cell count $)^{0.660} ; R^{2}=0.926$

WS4 : CFU $=3.185$ (total cell count $)^{0.902} ; R^{2}=0.925$,

WS5 : CFU $=1.566(\text { total cell count })^{0.626} ; R^{2}=0.869$

The coefficients of determination $\left(R^{2}\right)$ were superior or equal to 0.9 in all equations, except of WS2 and WS5, for which it was of 0.86 for both media.

At a given total cell count, the highest value of constant «b», gives the greatest value of CFU count. This is the case of CM and WS4, for which the constant « $b$ » was of 0.987 and 0.902 , respectively. However, this constant was lower than 0.7 for the other media causing a lower CFU count.

\section{Relationship between total cell count and toxicity}

The logarithmic function was found to be the best relationship to express the relation between total cell count and toxicity. This relation was expressed by the following equation: total cell count $=a \operatorname{Ln}$ (Toxicity) $+b$ and was presented in semi-log plots (Fig. 3b). The semi-log equations from (7) to (12), obtained by using different fermentation media are as follows:

$\mathrm{MC}:$ total cell count $=3.662 \operatorname{Ln}($ Toxicity $)+1.339 ; R^{2}=0.995$,

WS1 : total cell count $=2.473 \operatorname{Ln}($ Toxicity $)+4.276 ; R^{2}=0.997$,

WS2 $:$ total cell count $=2.501 \mathrm{Ln}($ Toxicity $)+4.468 ; \mathrm{R}^{2}=0.976$

(See figure on next page.)

Fig. 1 P. temperata bioinsecticide production in different fermentation media. a Growth, b CFU count and c toxicity. Error bars represent the standard errors of the mean values $(n=3)$. Letters ( $a, b, c, d$, e and $f)$ above each column indicate significant differences among oral toxicity of the strain $\mathrm{K} 122$, cultured in different media at $p<0.05$ according to the Duncan's test. Letters (A, B) above columns indicate significant differences among oral toxicity of the strain K122, cultured at different incubation times at $p<0.05$ according to the Duncan's test 

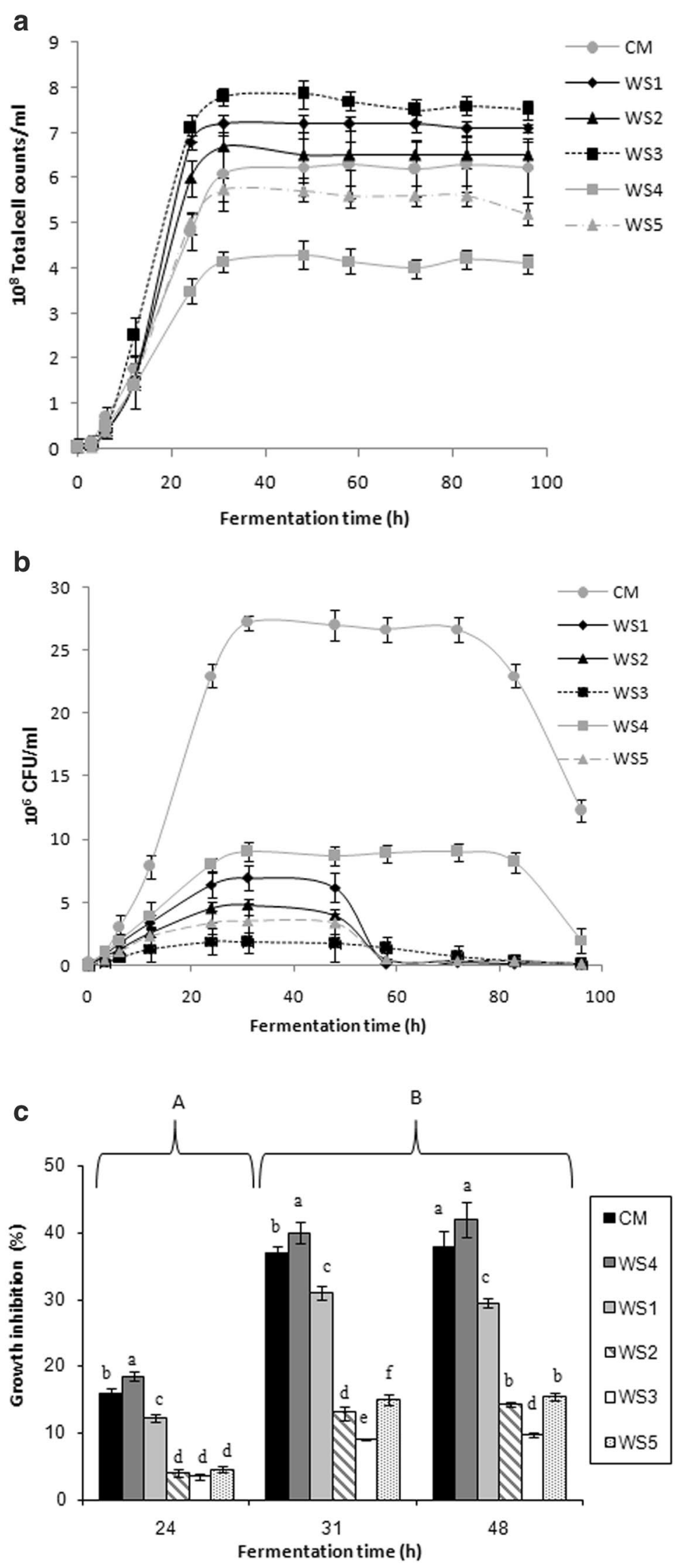
WS3 $:$ total cell count $=2.502 \operatorname{Ln}($ Toxicity $)+6.020 ; R^{2}=0.991$,

WS4 : total cell count $=2.993 \operatorname{Ln}($ Toxicity $)+0.3 ; R^{2}=0.999$,

WS5 $:$ total cell count $=2.743 \operatorname{Ln}($ Toxicity $)+3.216 ; R^{2}=0.973$.

The semi-log relationship between $P$. temperata total cell count and toxicity, was highly correlated in all the media tested $\left(R^{2}>0.9\right)$.

\section{Relationship between CFU count and toxicity}

To study the relationship between CFU count and entomotoxicity of $P$. temperata in different media, culturability was plotted against insecticidal activity. As shown in Fig. 3c, there is a logarithmic relationship between CFU and P. temperata entomotoxicity expressed by the following equation: $\mathrm{CFU}$ count $=a \mathrm{Ln}$ (toxicity) $+b$. By using different fermentation media, different equations from (13) to (18) were obtained:

$$
\begin{aligned}
& \text { MC }: \text { CFU }=16.29 \operatorname{Ln}(\text { Toxicity })+6.201 ; R^{2}=0.999, \\
& \text { WS1 }: \text { CFU }=2.331 \operatorname{Ln}(\text { Toxicity })+4.13 ; R^{2}=0.999, \\
& \text { WS2 }: \text { CFU }=1.797 \operatorname{Ln}(\text { Toxicity })+3.304 ; R^{2}=0.968, \\
& \text { WS3 : CFU }=0.491 \operatorname{Ln}(\text { Toxicity })+1.512 ; R^{2}=0.995, \\
& \text { WS4 : CFU }=6.333 \operatorname{Ln}(\text { Toxicity })+0.738 ; R^{2}=0.992, \\
& \text { WS5 : CFU }=1.606 \operatorname{Ln}(\text { Toxicity })+2.047 ; R^{2}=0.918 .
\end{aligned}
$$

High correlation between CFU count and entomotoxicity has been recorded in this study $\left(R^{2}>0.9\right)$.

\section{Discussion}

Industrial waste water is characterized by high nutrient content. For this reason researchers have directed their thoughts to the reuse of this effluent for the production of value-added products such as biopesticides. Indeed,
Yezza et al. (2006) demonstrated that starch industry wastewater containing high concentration of carbon (51.8\%, dry TS), allowed growth, sporulation and also toxin synthesis by Bacillus thuringiensis at a higher level than the reference medium. Moreover, wastewater sludge was demonstrated to be an effective medium for the growth of B. thuringiensis (Brar et al. 2009; Lachhab et al. 2001; Vidyarthi et al. 2002; Yezza et al. 2006). Containing high TOC concentration, this effluent, can be also used as a substrate for growth and as a carrier for Sinorhizobium meloliti (Ben Rebah et al. 2002).

As expected, the chemical and physical Tunisian industrial wastewater composition varied according to the origin of each one. This variability was observed in metal concentration, organic matter content and in carbon and nitrogen concentration; giving a large variation in $\mathrm{C} / \mathrm{N}$ ratio. Chemical characterization of different wastewaters showed that they contain several metals required for bacterial growth like $\mathrm{Ca}^{2+}, \mathrm{Mg}^{2+}, \mathrm{Na}^{+}$and $\mathrm{K}^{+}$. Indeed, magnesium is the most abundant divalent metal in cells and it is required for many structural and enzymatic functions (Wakeman et al. 2014). Calcium and calciumbinding are implicated in different processes in bacteria including: sporulation, virulence, transport of sugar and protein, phosphorylation, heat shock, initiation of deoxyribonucleic acid (DNA) replication, septation, nucleoid structure, nuclease activity and recombination (Norris et al. 1991). Sodium is involved in the relaxation of the plasmid DNA of Escherichia coli, the improvement of $P$. temperata biomass production and toxin synthesis (Jallouli et al. 2011). Moreover, potassium acts as a cytoplasmic signaling molecule, inducing adaptation to elevated osmolarity (Epstein 2003). In this study, we found that the studied wastewaters contain heavy metals, but at the recommended level according to the Tunisian agriculture use (Ben Abdallah and Neubert 2003). It is important to note that some heavy metals such as $\mathrm{Zn}^{2+}, \mathrm{Mn}^{2+}$ and $\mathrm{Fe}^{2+}$ are crucial for bacterial growth (Hughes and 
$\mathbf{A}$
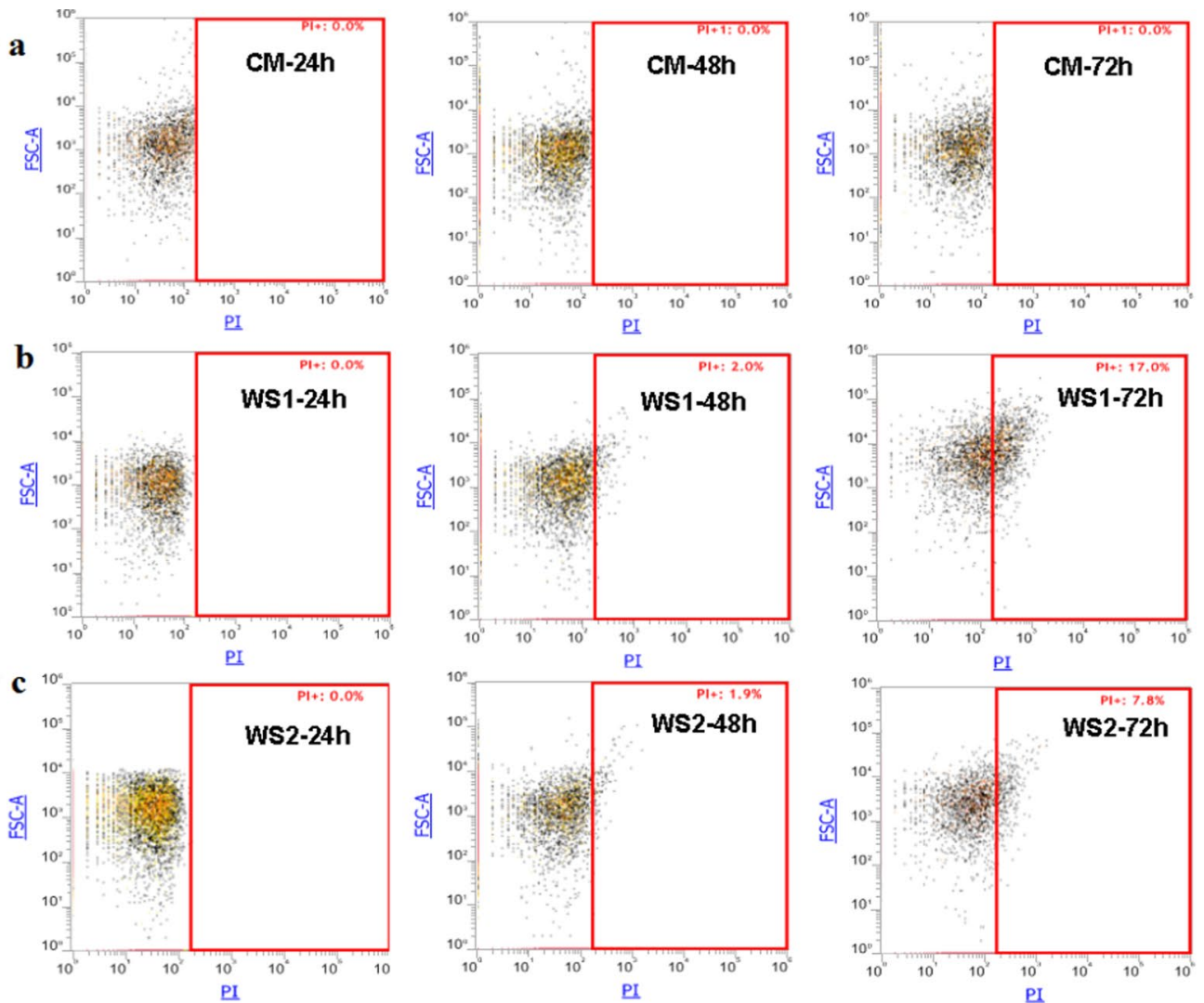

B
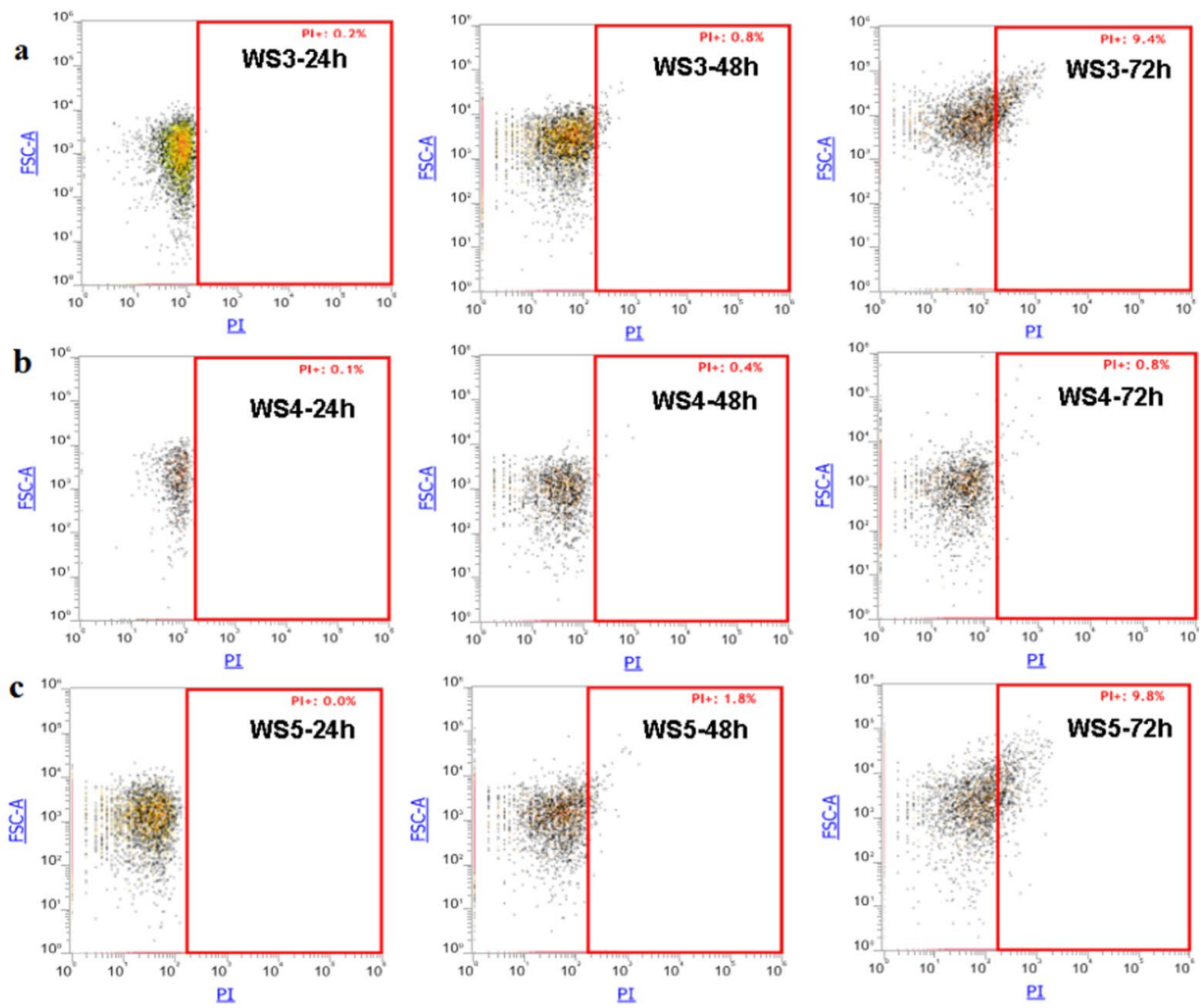
Poole 1991). Others like $\mathrm{Ni}^{2+}$ and $\mathrm{Cu}^{2+}$ can be toxic for bacterial cell growth. However, metals are generally less toxic when complexed with wastewater organic matter, than in free ionic forms (Babich and Stotzky 1980). Based on the obtained results, Tunisian industrial wastewaters used in this study seemed to have a good potential as an alternative medium for Photorhabdus bioinsecticide production. Indeed, wastewater contains carbon and nitrogen that could support the growth of $P$. temperata cells and could stimulate toxin synthesis by this bacterium. Moreover, the presence of mineral salts and some heavy metals in wastewater, avoids the addition of these compounds, playing a major role in cell growth. Interestingly, P. temperata fermented broth could be directly used as biopesticides. Indeed, industrial wastewater is sterilized before inoculation removing all possible contamination by pathogens. In addition, heavy metals are present at a low concentration (Table 1). Similarly, Brar et al. (2009), Lachhab et al. (20200101), Vidyarthi et al. (2002), and Yezza et al. (2006) used directly the fermented wastewater and wastewater sludge which are subjected to a concentration step and then formulation prior to application as $B$. thuringiensis biopesticide.

Our results showed that when using different industrial wastewaters for $P$. temperata cells production comparable sigmoid growth curves were obtained (Fig. 1A). Thus, it is evident that the strain K122 did not exhibit particular requirement for its growth and it was able to assimilate complex organic matter, present in different wastewaters used. Similar results have been reported by Jallouli et al. (2008) demonstrating the ability of P. temperata strain $\mathrm{K} 122$ to assimilate distinct nitrogen and carbon sources, with no need for any particular requirement, when growth occurred in the synthetic media.

Except for WS4, P. temperata cells production was correlated with carbon and nitrogen contents in all tested wastewaters. Indeed, the lowest biomass production was obtained when using WS5, having the lowest total carbon of $144.6 \mathrm{mg} / \mathrm{L}$ and a total nitrogen of $17.5 \mathrm{mg} / \mathrm{L}$, while the highest biomass production was obtained when using WS3 having a total carbon and nitrogen of $1753 \mathrm{mg} / \mathrm{L}$ and $83.3 \mathrm{mg} / \mathrm{L}$, respectively. Despite its high nitrogen and carbon content, low $P$. temperata biomass production was obtained in the case of WS4. This could be explained by the fact that this wastewater may contain organic compounds, which could be responsible for the inhibition of K122 cell multiplication.
On the other hand, it was obviously clear that irrespective of the medium used for $P$. temperata growth, the highest CFU counts was not observed at the highest total cell counts. Moreover, culturability in all cases was lower than total cell count (Fig. 1B) which illustrates the VBNC state of $P$. temperata. This state has been demonstrated when growth occurred in the optimized medium (OM), based on glucose and yeast extract, or the $\mathrm{CM}$ with a culturability of 11.1 and $4.35 \%$, respectively (Jallouli et al. 2008, 2011). Here, we demonstrated that cultivation in wastewater enhances the VBNC state since $P$. temperata culturability after $48 \mathrm{~h}$ incubation reached only $2.02,0.86$, $0.61,0.58$ and $0.21 \%$ of the total cell counts in WS4, WS1, WS2, WS5 and WS3, respectively, compared to $4.32 \%$ obtained by using CM. However, until $48 \mathrm{~h}$ of incubation, almost $100 \%$ of $P$. temperata cells were viable according to PI single stained dot plot (Fig. 2). After a prolonged incubation in wastewater $(72 \mathrm{~h})$, the physiological state of the strain K122 changed and PI positively stained cells appear, indicating the loss of $P$. temperata cell-membrane integrity, leading to cell death. This state could be the result of reactive oxygen species accumulation in $\mathrm{K} 122$ cells during growth as demonstrated by Jallouli et al. (2010). Reactive oxygen species, especially hydrogen peroxide, were demonstrated to be responsible of $P$. temperata inability to form colonies since they remain close to the cells, contrarily to liquid medium, in which they diffuse away from the cells. This was observed during the growth in WS3, since K122 cells had the lowest CFU count of $1.7 \times 10^{6}$ cells $/ \mathrm{mL}$ ( $48 \mathrm{~h}$ ) despite the highest cell counts obtained in the same medium. Our study proved also instability of $P$. temperata cells to form colonies during growth in different fermentation media. The decline in CFU counts from $48 \mathrm{~h}$ in WS1, WS2, WS3 and WS5 could be attributed to organic matter heterogeneity and consequently, the variability of produced metabolites during fermentation influencing K122 cells capacity to form colonies after plating in LB solid medium. However, K122 cells grown in WS4 remained culturables, similarly to those grown in CM indicating that WS4 could be a suitable medium for the maintaining of $P$. temperata culturability. Interestingly, by using wastewater as a fermentation medium for $P$. temperata bioinsecticide production, Vsm polymorphism was completely avoided (result not shown) since no K122 colony forms (white, red or yellow) were observed when plating cells on solid medium, even after extended incubation. Similar results were reported for CM medium, in which Vsm

(See figure on next page.)

Fig. 3 Correlation profiles between a total cell count and CFU count; $\mathbf{b}$ total cell count and toxicity and $\mathbf{c}$ CFU count and toxicity during fermentation in different media 

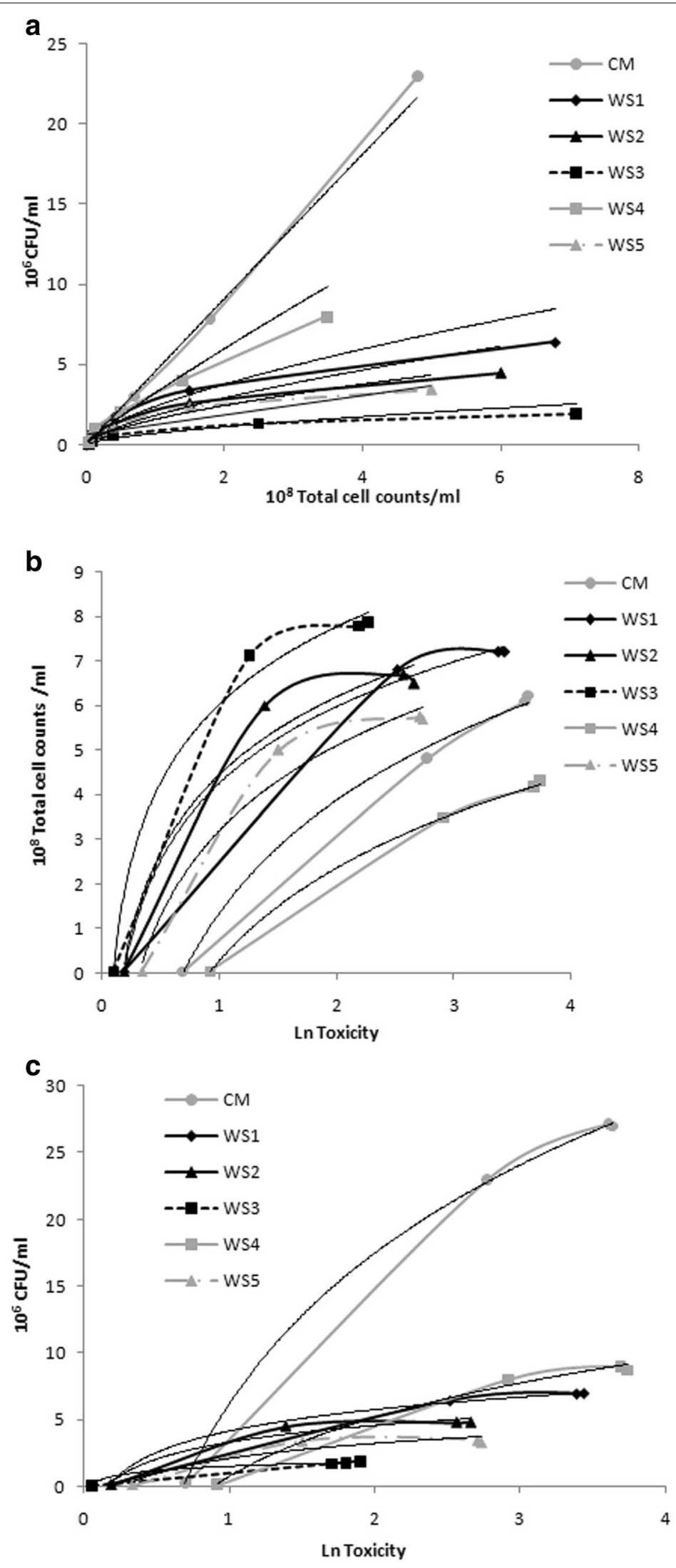
appearance was avoided (Jallouli et al. 2011). Such forms were demonstrated to be less toxic and consequently reduce the efficacy of $P$. temperata bioinsecticide (Jallouli et al. 2008).

Assessment of $P$. temperata oral toxicity against $E$. kuehniella larvae showed that the highest toxicity was obtained in WS4 in which the highest nitrogen concentration was of $403.2 \mathrm{mg} / \mathrm{L}$. These results could be explained by the fact that organic compounds present in WS4 limit $P$. temperata growth, but have no effect on the culturability or toxin synthesis of the produced cells. Moreover, the low nitrogen contents in WS1 $(77 \mathrm{mg} / \mathrm{L})$, WS2 (76.3 mg/L), WS5 (17.5 mg/L) and WS3 $(83.3 \mathrm{mg} / \mathrm{L})$ could explain the low toxin synthesis in these media. High oxidative stress could be another factor responsible of low toxicity $(9.75 \%)$ obtained when growth occurred in WS3, since reactive oxygen species not only affect $P$. temperata ability to form colonies, but also influence toxin gene expression (Jallouli et al. 2011). Further analysis by flow cytometry should be performed to confirm such hypothesis.

Irrespective of the wastewater used for $P$. temperata cultivation, K122 cells aged for $31 \mathrm{~h}$ exhibited the same toxicity to those aged for $48 \mathrm{~h}$ (Fig. 1C). However, by using the same cell density of $4 \times 10^{8}$ cells $/ \mathrm{mL}$, oral toxicity was the lowest after $24 \mathrm{~h}$ of incubation in all fermentation media. This result was in accordance with those reported by Jallouli et al. (2013), demonstrating that the maximum of toxin synthesis occurred at $32 \mathrm{~h}$ of incubation. Based on these findings, WS4 medium is a suitable medium for $P$. temperata bioinsecticide production since $P$. temperata cells exhibited the highest toxicity, culturability and physiological state stability.

The analysis of total cell count, CFU count and toxicity during $P$. temperata growth in different fermentation media, was conducted to have a possible mathematical relationships between all these parameters. These relationships have never been reported in literature for P. temperata strain K122. In this study, we showed for the first time that irrespective of the medium used, the relationship between total cell and CFU counts followed the power law (Fig. 3a). Consequently, it is possible to calculate the CFU count in each medium, knowing only total cell count. A similar relationship was found between B. thuringiensis-specific entomotoxicity and spore concentration (Brar et al. 2009; Vu et al. 2012). In the obtained power law equations, the coefficient " $a$ " is a direct measure of CFU count at a given total cell count value. The value of coefficient " $a$ " in different media follows the order $\mathrm{CM}>\mathrm{WS} 4>\mathrm{WS} 1>$ WS2 $>$ WS5 $>$ WS3 which is in accordance with results obtained in Fig. 1B, since the ability of P. temperata to form colonies follows the same order. These results were in agreement with nitrogen and carbon contents since these nutrients were present at high concentration in CM followed by WS4, WS1, WS2 and finally WS5 (Table 1). Regardless of its high nutrient content, WS3 has the smallest value of constant " $a$ " ( $a$ : 0.68), which reflects the lowest CFU count. This is probably due to oxidative stress generation during $P$. temperata cell growth in such wastewater and thus affecting K122 ability to form colonies after plating in LB solid medium. Additionally, it is particularly interesting to note that by using CM or WS4 for P. temperata bioinsecticide production, a linear relation in semi-log scale was obtained between total cell count and toxicity (Fig. 3b). As a result, growth inhibition of E. kuehniella larvae increases with total cell count up to a certain value $(32 \mathrm{~h})$ after which toxicity remains stable. The obtained results could be justified by the fact that cells aged for $48 \mathrm{~h}$ or $32 \mathrm{~h}$ exhibited the same oral toxicity against E. kuehniella larvae. Similarly, Jallouli et al. (2013) reported that $P$. temperata oral toxicity rises by increasing cell concentration. However, by using other wastewaters (WS1, WS2, WS3 and WS5), toxicity continued to increase despite the stabilization of total cell counts. In these cases, $P$. temperata biomass production did not differ significantly between $24 \mathrm{~h}, 32 \mathrm{~h}$ or $48 \mathrm{~h}$, contrarily to toxicity which greatly increased by the increase in P. temperata toxin synthesis from $32 \mathrm{~h}$ (Jallouli et al. 2013). Similarly, the relationship between CFU count and toxicity was found to be linear on semi$\log$ scale. As expected, high culturability did not reflect high toxicity, since $P$. temperata cultured-cells in CM and having the highest CFU count, had similar toxicity to $P$. temperata cultured-cells in WS4. This could be explained by the fact that $P$. temperata in the VBNC state exhibited the same toxicity as the viable ones (Jallouli et al. 2013). Another study also reported that a logarithmic relationship was obtained when plotting $B$. thuringiensis entomotoxicity against delta-endotoxin concentration ( $\mathrm{Vu}$ et al. 2012). However, a linear relation was obtained between $B$. thuringiensis entomotoxicity and protease activity (Brar et al. 2009) as well as between $B$. thuringiensis entomotoxicity and specific growth rate (Vidyarthi et al. 2002). Consequently, to estimate $P$. temperata bioinsecticide production during fermentation, the linear relation between Ln (toxicity) and total cell count or Ln (toxicity) and CFU count could be used. Thus, a rapid determination of total cell count microscopically or $P$. temperata culturability could be a useful method to predict $P$. temperata entomotoxicity. However, these equations should be used only to follow bioinsecticide production during fermentation or to estimate maximal $P$. temperata oral toxicity obtained after $48 \mathrm{~h}$ of incubation. But, bioassay 
remains the best method to have the correct growth inhibition of E. kuehniella larvae considering the insecticidal protein diversity and the change in wastewater composition.

\section{Conclusions}

Considering the increase in industrial wastewater discharge in nature and its effects on the environment, bioconversion to value-added products like bioinsecticide appears as a good alternative. This approach not only reduces the quantity of wastewater through its use as a raw material, but also contributes to the production of low-cost bioinsecticide based on the entomopathogenic bacterium $P$. temperata, since wastewater contains carbon, nitrogen and other nutrient sources required for its growth. In the present study, we showed that performance of the strain K122 in growth, culturability, viability and toxicity varied within the five Tunisian industrial wastewaters disposed. This variation could be due to the variability in nitrogen and carbon concentration according to the wastewater origin. Moreover, the presence of organic compounds in wastewater and the generation of reactive oxygen species during fermentation could be involved in the decrease of $P$. temperata's ability to multiply, to form colonies on the solid medium or to exhibit oral toxicity. Further studies are needed to confirm the involvement of such molecules or components in $P$. temperata bioinsecticide production. Besides, study of the mathematical relationships between all determined parameters, showed that the CFU count followed power law when plotted against total cell count. Moreover, the relations between toxicity, total cell count and toxicity, CFU count were found to be linear on semi-log scale. Thus, the progress of $P$. temperata fermentation process can be easily followed by using the relationships established between the fermentation parameters.

\begin{abstract}
Abbreviations
P. temperata: Photorhabdus temperata; (WS1, WS2, WS3, WS4, WS5): Indusrial wastewaters; CM: Complex medium; Vsm: Variants small colony; VBNC: Viable but non-culturable; CFU: Colony-forming units; PI: Propidium iodide; COD: Carbon oxygen demand; Tc: Toxin complexes; Mcf: Makes caterpillars floppy; E. kuehniella: Ephestia kuehniella; G. mellonella: Galleria mellonella; TS: Total solids; VS: Volatile solids; SS: Suspended solids; VSS: Volatile suspended solids; Nt: Total nitrogen; TOC: Total organic carbon; OD: Optical density; B. thuringiensis: Bacillus thuringiensis; DNA: Deoxyribonucleic acid; OM: Optimized medium.
\end{abstract}

\section{Acknowledgements}

This work was supported by Grants from the "Ministry of Higher Education and Scientific Research".

\section{Authors' contributions}

KS performed fermentation experiments. JW wrote the paper and conceived the experiments. SE performed cytometry analysis. SS designed and collected wastewaters characterization. TS developed the manuscript. All authors read and approved the final manuscript.
Funding

Not applicable.

Availability of data and materials

All data generated or analyzed during this study are included in this article.

Ethics approval, consent to participate and consent for publication The authors have read and approved the manuscript to submit it to Bioresources and Bioprocessing.

\section{Competing interests}

The authors declare that they have no competing interests.

\section{Author details}

${ }^{1}$ Biopesticides Laboratory, Centre of Biotechnology of Sfax, Sfax University, P.O. Box'1177', 3018 Sfax, Tunisia. ${ }^{2}$ Analysis Laboratory, Centre of Biotechnology of Sfax, Sfax University, P.O. Box'1177', 3018 Sfax, Tunisia. ${ }^{3}$ Center for Sustainable Development, College of Arts and Sciences, Qatar University, Doha 2713, Qatar.

Received: 4 February 2020 Accepted: 5 May 2020

Published online: 11 May 2020

\section{References}

APHA, AWWA, WPCF (1992) Standard methods for the examination of water and wastewater. 18: 518-523

Babich H, Stotzky G (1980) Environmental factors that influence the toxicity of heavy metal and gaseous pollutants to microorganisms. Crit Rev Microbiol 8:99-145

Ben Abdallah S, Neubert S (2003) La réutilisation des eaux usées traitées en Tunisie études et rapports d'expertise. Institut Allemand de développement, GTZ

Ben Rebah F, Tyagi RD, Prevost D (2002) Wastewater sludge as a substrate for growth and carrier for Rhizobia: the effect of storage conditions on survival of Sinorhizobium meliloti. Bioresour Technol 83:145-151

Brar SK, Verma M, Tyagi RD, Valéro JR, Surampalli RY (2009) Entomotoxicity, protease and chitinase activity of Bacillus thuringiensis fermented wastewater sludge with a high solids content. Bioresour Technol 100:4317-4325

Daborn PJ, Waterfield N, Silva CP, Au CPY, Sharma S (2002) A single Photorhabdus gene, makes caterpillars floppy (mcf), allows Escherichia coli to persist within and kill insects. Proc Natl Acad Sci 99:10742-10747

Epstein W (2003) The roles and regulation of potassium in bacteria. Prog Nucleic Acid Res Mol Biol 75:293-320

Eroglu C, Cimen H, Ulug D, Karagoz M, Hazir S, Cakmak I (2019) Acaricidal effect of cell-free supernatants from Xenorhabdus and Photorhabdus bacteria against Tetranychus urticae (Acari: Tetranychidae). J Invertebr Pathol 160:61-66

Gupta S, Pawar SB, Pandey RA (2019) Current practices and challenges in using microalgae for treatment of nutrient rich wastewater from agro-based industries. Sci Total Environ 687:1107-1126

Hughes MN, Poole RK (1991) Metal speciation and microbial growth-the hard (and soft) facts. J Gen Microbiol 137:725-734

Jallouli W, Hammami W, Zouari N, Jaoua S (2008) Medium optimization for biomass production and morphology variance overcome of Photorhabdus temperata ssp. temperata strain K122. Process Biochem 43:1338-1344

Jallouli W, Zouari N, Jaoua S (2010) Involvement of oxidative stress and growth at high cell density in the viable but non culturable state of Photorhabdus temperata ssp. temperata strain K122. Process Biochem 45:706-713

Jallouli W, Jaoua S, Zouari N (2011) Overcoming the production limitations of Photorhabdus temperata ssp. temperata strain K122 bioinsecticides in low-cost medium. Bioprocess Biosyst Eng 34:1039-1047

Jallouli W, Abdelkefi ML, Tounsi S, Jaoua S, Zouari N (2013) Potential of Photorhabdus temperata K122 bioinsecticide in protecting wheat flour against Ephestia kuehniella. J Stored Prod 53:61-66

Jang EK, Ullah I, Kim MS, Lee KY, Shin JH (2011) Isolation and characterisation of the entomopathogenic bacterium, Photorhabdus temperata producing a heat stable insecticidal toxin. Plant Dis Res 118:178-184

Kjeldahl J (1883) A new method for the determination of nitrogen in organic matter. Anal Chem 22:366 
Lachhab K, Tyagi RD, Valéro JR (2001) Production of Bacillus thuringiensis biopesticides using wastewater sludge as a raw material: effect of inoculum and sludge solids concentration. Process Biochem 37:197-208

Montiel MDLT, Tyagi RD, Valero JR (2001) Wastewater treatment sludge as a raw material for the production of Bacillus thuringiensis based biopesticides. Water Res 35:3807-3816

Norris V, Chen M, Goldberg M, Voskuil J, MoGurk G, Holland B (1991) Calcium in bacteria: a solution to which problem? Mol Microbiol 5:775-778

Rezapour S, Atashpaz B, Moghaddam SS, Damalas CA (2019) Heavy metal bioavailability and accumulation in winter wheat (Triticum aestivum L.) irrigated with treated wastewater in calcareous soils. Sci Total Environ 656:261-269

Sambrook J, Fritsch EF, Maniatis T (1989) Molecular cloning: a laboratory manual. Cold Spring Harbor Laboratory Press, Cold Spring Harbor

Shrestha YK, Lee KY (2012) Oral toxicity of Photorhabdus culture media on gene expression of the adult sweetpotato whitefly, Bemisia tabaci. J Invert Pathol 109:91-96

Stock SP, Griffin CT, Burnell AM (2002) Morphological characterisation of three isolates of Heterorhabditis Poinar, 1976 from the 'Irish group' (Nematoda: Rhabditida: Heterorhabditidae) and additional evidence supporting their recognition as a distinct species, H. downesi $n$. sp. Syst Parasitol 51:95-106

Ullah I, Jang EK, Kim MS, Shin JH, Park GS, Khan AR, Kwak Y (2014) Identification and characterization of the insecticidal toxin "makes caterpillars floppy" in Photorhabdus temperata M1021 using a cosmid library. Toxins 6:2024-2040

Ullah I, Anwar Y, Al-Ghamdi K, Firoz A, Shin JH (2017) Assessment of agriculturally important metabolites from the entomopathogenic bacterium Photorhabdus temperata M1021. J Exp Biol Agric Sci 5:907-914
Vidyarthi AS, Tyagi RD, Valero JR, Surampalli RY (2002) Studies on the production of $B$. thuringiensis based biopesticides using wastewater sludge as a raw material. Water Res 36:4850-4860

Vu KD, Tyagi RD, Surampalli RY, Valero JR (2012) Mathematical relationships between spore concentrations, delta-endotoxin levels, and entomotoxicity of Bacillus thuringiensis preparations produced in different fermentation media. Bioresour Technol 123:303-311

Wakeman CA, Goodson JR, Zacharia VM, Winkler WC (2014) Assessment of the requirements for magnesium transporters in Bacillus subtilis. J Bacteriol 196:1206-1214

Waterfield NR, Bowen DJ, Fetherston JD, Perry RD (2001) The tc genes of Photorhabdus: a growing family. Trends Microbiol 9:185-191

Yezza A, Tyagi RD, Valero JR, Surampalli RY (2006) Bioconversion of industrial wastewater and wastewater sludge into Bacillus thuringiensis based biopesticides in pilot fermentor. Bioresour Technol 97:1850-1857

Zouari M, Souguir D, Bloem E, Schnug E, Hanchi B, Hachicha M (2019) Saline soil reclamation by agroforestry species under Kalaat Landelous conditions and irrigation with treated wastewater in Tunisia. Environ Sci Pollut Res Int 26:28829-28841

\section{Publisher's Note}

Springer Nature remains neutral with regard to jurisdictional claims in published maps and institutional affiliations.

\section{Submit your manuscript to a SpringerOpen ${ }^{\circ}$ journal and benefit from:}

- Convenient online submission

- Rigorous peer review

- Open access: articles freely available online

- High visibility within the field

Retaining the copyright to your article

Submit your next manuscript at $\boldsymbol{\nabla}$ springeropen.com 